\title{
Genetic Parameters of Agronomic Traits in Sweetpotato Accessions
}

\author{
Wiwit Rahajeng*, Joko Restuono, Febria Cahya Indriani, Purwono
}

Indonesian Legumes and Tuber Crops Research Institute, Indonesia

*Email: wiwit.rahajeng@gmail.com

Submitted: 18 March 2020. Revised: 19 May 2020. Accepted: 20 July 2020

\begin{abstract}
Germplasm as a source of genes in sweetpotato breeding requires information on appearance and genetic parameters. The objectives of this research were to determine the performance and genetic parameters of sweet potato accessions. The research was conducted at Kendalpayak Research Station, Malang, East Java, Indonesia. The materials used were thirty sweet potato accessions from Indonesian Legumes and Tuber Crops Research Institute (ILETRI) germplasm collection. The research was arranged in a Randomized Block Design (RBD) with two replications. The variables observed included: the vines length, the weight of vines, the number and weight of the saleable root per plot, the number and weight of the non-saleable root per plot, the number and weight of root per plant, the root yield, the harvest index, and the dry matter content. The results of ANOVA showed a significant difference among the tested genotypes in almost all traits observed except on weight of non-saleable root. PCV estimation was higher than GCV estimation for all the observed characters. The weight of the saleable root per plot, the weight of root per plant, and the root yield that showed a wide range of PCV and GCV as well as high broad-sense heritability indicated that these traits had additive gene effect and more reliable for effective selection. The broad GCV in a population is effective for selection to obtain the superior variety.
\end{abstract}

Key words: Genetic Advance; Genetic Variation; Heritability; Ipomoea batatas; Sweet Potato

How to Cite: Rahajeng, W., Restuono, J., Indriani, F. C., \& Purwono, P. (2020). Genetic Parameters of Agronomic Traits in Sweetpotato Accessions. Biosaintifika: Journal of Biology \& Biology Education, 12 (2), 240-246

DOI: http://dx.doi.org/10.15294/biosaintifika.v12i2.23780

\section{INTRODUCTION}

Sweet potato (Ipomoea batatas L.) is one of the important staples food in Indonesia. It is the fourth source of carbohydrate after rice, corn and cassava. It also contain fiber, vitamins, minerals, antioxidants, and have a low glycemic content. Sweet potatoes play an important role in the supply of industrial raw materials and animal feed (Wera et al., 2014; Pradhan et al., 2015). The development and improvement of sweet potato's productivity is needed to meet those needs. Productivity improvements can be made through the breeding programs.

Breeding programs will succeed if supported by information of economic value, wide diversity, and high inheritance of the character to be corrected. Therefore, understanding the diversity of sweet potato genotypes based on agronomic traits is very important in planning sweet potato breeding programs and determining effective selection criteria (Ngailo et al., 2016; Selaocoe et al., 2019). Selection in breeding programs is the basis of all improvements to get new superior varieties. Efficient selection will be obtained by using several genetic parameters and heritability as considerations. According to Palumbo et al., (2019) and Irwan et al., (2019), wide genetic diversity is one of the conditions for an effective selection program, and selection for a desired character will be more meaningful if the character is easily inherited.
Another important component that determines the success of a variety assembly program is information about inheritance (heritability values) and characters that are positively correlated with root yields. Breeders need this information to determine their selection strategies and criteria. Studies on parameters genetic and heritability has been done by researchers. Shaumi et al., (2012); Madawal et al., (2015); Rahajeng and Rahayuningsih (2016); EL-Sharkawy (2019) reported that jumlah dan bobot umbi serta hasil umbi adalah the characters with the high and moderate heritability and genetic advance can be considered for direct selection for sweet potato improvement.

The objectives of this research were to determine the performance and genetic parameters of sweet potato accessions from the germplasm bank of Indonesian Legumes and Tuber Crops Research Institute (ILETRI). Information about the performance and genetic parameters of sweet potato accessions from this study is expected to be utilized for sweet potato breeding programs.

\section{METHODS}

The research was conducted in February-June 2017 at Kendalpayak Research Station, Malang, East Java, Indonesia. Kendalpayak Research Station lies at $8^{\circ} 2^{\prime} 56.4^{\prime \prime} \mathrm{LS} 112^{\circ} 37^{\prime} 30^{\prime \prime} \mathrm{BT}$ with an altitude of 445 
m a.s.l. The average annual rainfall was $2191 \mathrm{~mm}$ with a minimum/maximum mean air temperature of $17.5 / 30{ }^{\circ} \mathrm{C}$. The soil was classified as Entisol and the textural class was clay with $\mathrm{pH}$ of 5.8.

The material used was thirty sweet potato accessions from Indonesian Legumes and Tuber Crops Research Institute (ILETRI) germplasm collection. The research was arranged in a Randomized Block Design (RBD) with two replications. Each accession was planted on $5 \mathrm{~m} \times 1 \mathrm{~m}$ (single row), which accommodated 20 plants (the spacing between plants was $25 \mathrm{~cm})$. Fertilizer $(300 \mathrm{~kg} / \mathrm{ha}$ of NPK Phonska) was applied at planting $(2 / 3$ dose $)$ and 5 weeks after planting ( $1 / 3$ dose). Weeding was done at 4,7 , and 10 weeks after planting. Irrigation, pest, and disease control was applied as needed. Harvesting was done after 4 months of planting.

Table 1. List of the sweet potato accessions from ILETRI germplasm collection

\begin{tabular}{|c|c|c|c|}
\hline Accessions Origin & Flesh Color & No. Accessions Origin & Flesh Color \\
\hline MLGI 0001 Probolinggo, E-Java & White & 16. MLGI 0037 Klungkung, Bal & White \\
\hline MLGI 0004 Bondowoso, E-Java & White & 17. MLGI 0046 Bangli, Bali & White \\
\hline MLGI 0005 Banyuwangi, E-Java & White & 18. MLGI 0047 Bangli, Bali & Yellow \\
\hline MLGI 0006 Banyuwangi, E-Java & Yellow-Purple & 19. MLGI 0048 Bangli, Bali & White \\
\hline MLGI 0009 Banyuwangi, E-Java & Yellow & 20. MLGI 0050 Gianyar, Bali & White \\
\hline MLGI 0011 Jember, E-Java & Yellow & 21. MLGI 0057 Tabanan, Bali & White \\
\hline MLGI 0012 Jember, E-Java & Yellow & 22. MLGI 0058 Tabanan, Bali & White \\
\hline MLGI 0014 Lumajang, E-Java & White & 23. MLGI 0059 Tabanan, Bali & Yellow \\
\hline MLGI 0018 Blitar, E-Java & White & 24. MLGI 0065 Donor BORIF & White \\
\hline MLGI 0021 Kediri, E-Java & White & 25. MLGI 0066 Donor BORIF & Yellow \\
\hline MLGI 0023 Kediri, E-Java & White & 26. MLGI 0070 Donor BORIF & Yellow-Purple \\
\hline MLGI 0027 Buleleng, Bali & Yellow & 27. MLGI 0076 Donor BORIF & White \\
\hline MLGI 0030 Karangasem, Bali & White & 28. MLGI 0077 Donor BORIF & White \\
\hline MLGI 0031 Karangasem, Bali & Purple & 29. MLGI 0079 Donor BORIF & Yellow-Orange \\
\hline MLGI 0035 Karangasem, Bali & White & 30. MLGI 0080 Donor BORIF & Yellow \\
\hline
\end{tabular}

The variables observed included: the vines length $(\mathrm{cm})$, the weight of vines $(\mathrm{kg} / \mathrm{plot})$, the number of the saleable root per plot, the number of the non-saleable root per plot, the number of root per plant, the weight of the saleable root per plot $(\mathrm{kg})$, the weight of the non-saleable root per plot $(\mathrm{kg})$, the weight of root per plant $(\mathrm{kg})$, the root yield $(\mathrm{t} / \mathrm{ha})$, the harvest index, and the dry matter content (\%).

Data were analyzed by analysis of variance (ANOVA) using PKBT-STAT 1.0 program. Genetic parameter analysis (genotypic and phenotypic coefficients of variation, heritability, and genetic advances) was performed according to Syukur et al. (2009) and Demelie and Aragaw (2016). The deviation of genetic variance was used to determine the criteria of genetic variability.

\section{RESULT AND DISCUSSIONS}

\section{Analysis of Variance (ANOVA) and Mean Per- formance of Genotypes}

The ANOVA test for eleven characters showed significant differences among the genotypes for almost all characters observed except weight of the non-saleable root (Table 2). This may indicate that each accession showed a different genetic, especially for the vines length, weight of vines, number of the saleable root per plot, the number of root per plant, the weight of the saleable root per plot, the weight of the non-saleable root per plot, the weight of root per plant, the root yield, the harvest index, and the dry matter content and also had a wide variability among genotypes.

The performance of the agronomic traits in thirty sweet potato accessions are presented in Table 3 . Each trait of the accessions had a wide range of mean values. MLGI 0037 produce the highest yield, harvest index, and weight of root while MLGI 0031 showed the lowest value. The root dry matter content of thirty accessions had range between 23.64\% (MLGI 0014) and 34.93\% (MLGI 0006) with an average $28.70 \%$. Dry matter content of root is a critical parameter in the selection because it can be used as an indicator of root quality. According to Kathabwalika et al., (2013), the root dry matter content indicates mealiness in the roasted or boiled sweet potato, so that it becomes an important quality parameter in the food processing industry and determines consumer preferences. The farmer preference of the root dry matter content is > 25\% (Mbah and Eke-Okoro, 2015). Meanwhile for industry, the root dry matter content preference is $>30 \%$ (Rukundo et al., 2013). 


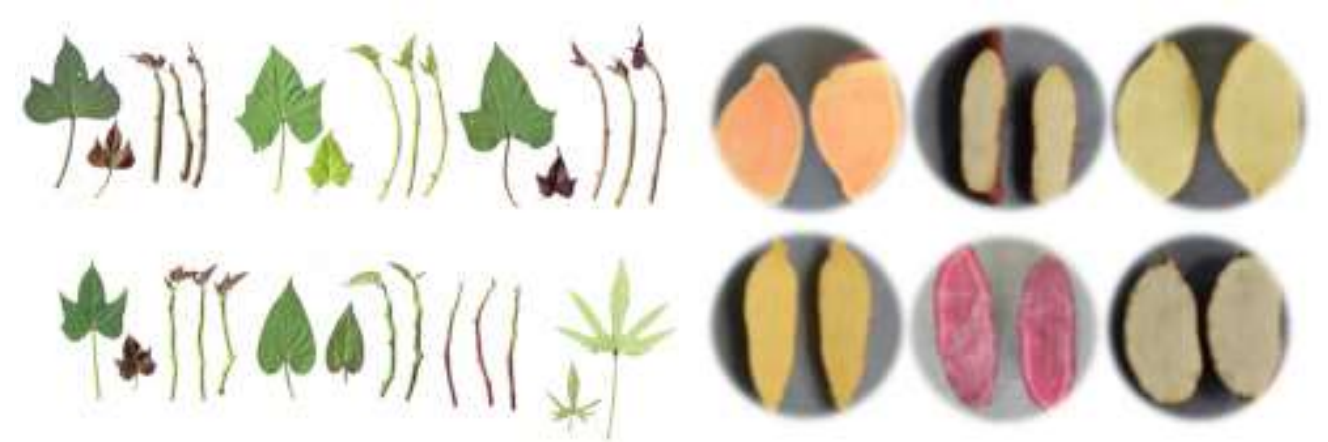

Figure 1. Morphological diversity of leaves and tubers of sweet potato accessions

Table 2. Analysis of variance for 11 characters in 30 sweetpotato accessions

\begin{tabular}{lcccc}
\hline \multirow{2}{*}{ Characters } & \multicolumn{3}{c}{ Mean square } & \multirow{2}{*}{ CV (\%) } \\
\cline { 2 - 5 } & Block & Genotype & Error & \\
\hline Vines length (VL) & $545.78^{\text {ns }}$ & $8,526.22^{* *}$ & 261.34 & 8.88 \\
Weight of vines (WV) & $52.45^{*}$ & $15.71^{* *}$ & 7.18 & 19.67 \\
Number of the saleable root (NSR) & $2.419 .35^{* *}$ & $328.26^{* *}$ & 86.94 & 36.16 \\
Number of the non-saleable root (NNSR) & $437.40^{*}$ & $287.58^{*}$ & 138.71 & 47.81 \\
Number of root per plant (NRP) & $3.35^{* *}$ & $2.88^{* * *}$ & 0.90 & 32.26 \\
Weight of the saleable root (WSR) & $63.63^{* *}$ & $25.36^{* *}$ & 4.13 & 39.99 \\
Weight of the non-saleable root (WNSR) & $0.22^{\text {ns }}$ & $0.51^{\text {ns }}$ & 0.31 & 54.87 \\
Weight of root per plant (WRP) & $0.20^{* *}$ & $0.09^{* * *}$ & 0.02 & 37.20 \\
Root yield (RY) & $326.01^{* *}$ & $141.68^{* *}$ & 27.95 & 37.22 \\
Harvest index (HI) & $0.01^{\text {ns }}$ & $0.03^{* *}$ & 0.01 & 25,38 \\
Dry matter content (DMC) & $0.14^{* *}$ & $17.00^{* *}$ & 0.01 & 0.33 \\
\hline
\end{tabular}

Note: $* *$ significant at $\mathrm{p}<0.01, *$ significant at $\mathrm{p}<0.05, \mathrm{~ns}=$ non significant

\section{Estimation of Genetic Variance Component}

In breeding programs, selection is the main activity to obtain superior varieties. Selection will run effectively if a population with a broad genetic diversity is available. So the opportunity to get the desired traits increases.

Table 4 shows eight characters (weight of vines, number and weight of root perplant, weight of saleable and non-saleable root perplot, root yield, harvest index, and dry matter content) of eleven characters observed which had broad genotypic coefficient of variation (GCV). These results are similar to the results of a study by Badu et al., (2017) and Sharavati et al., (2018) which obtained broad GCV for weight of vines, weight of root, and root yield. Vine length and number and weight of nonsaleable root per plot showed narrow GCV. In breeding program, broad GCV will expand the opportunity to improve these characters through selection, because it indicates the large amount of variation (Badu et al., 2017; Narasimhamurthy et al., 2018). A rigorous selection method should be done to select the characters with narrow GCV (Addisu et al., 2013; Kuswantoro et al., 2018).

Phenotypic coefficients of variation values were higher than genotypic coefficient of variation values with slight difference values for all the observed characters. Akinwale et al., (2010) and Baafi et al., (2016) stated that the diversity is also influenced by environmental factors besides the genetic factors. The slight difference in value between PCV and GCV shows that the influence of genetic factors is more dominant than the influence of environmental factors. The research of Demelie and Aragaw (2016) and Rahajeng and Indiati (2018) also showed the same results, PCV values were greater than GCV with a slight difference in values. If the value of PCV and GCV has a significant difference, it means that environmental factors have a high influence.

In addition to the coefficient of variance, information about inheritance is also important to determine the criteria for efficient selection. Kuswantoro et al., (2018) stated that the coefficient of variance only shows the variability of genotypes of the observed characters but does not provide information about the proportion of inheritance. Therefore, the value of heritability needs to be known to determine the pattern of inheritance. Heritability indicates the amount of influence of genetic factors or environmental factors on a character. The high heritability value shows that the character is more influenced by genetic factors. A character that has a high heritability value can be used as an effective selection criteria in the early generations (Chahal \& Gosal 2010; Afuape et al., 2015; Dewi et al., 2019). 
Table 3. Agronomic traits of thirty sweet potato accessions

\begin{tabular}{|c|c|c|c|c|c|c|c|c|c|c|c|c|}
\hline No & & VL & WV & NSR & JNSR & NRP & WSR & $2+1 v_{n}$ & $V R P$ & RY & HI & \\
\hline 1 & 1 & $97.80^{\mathrm{mn}}$ & 12.55 & $68.00^{\mathrm{a}}$ & $38.50^{\mathrm{a}-\mathrm{f}}$ & $6.48^{\mathrm{a}}$ & $9.82^{\mathrm{b}-\mathrm{d}}$ & $1.92^{\mathrm{ab}}$ & $0.72^{\mathrm{a}-\mathrm{c}}$ & $\overline{28.60}$ & $0.49^{\mathrm{ab}}$ & 29.88 \\
\hline 2 & & - & $13.70^{\mathrm{a}-\mathrm{g}}$ & $48.50^{\mathrm{b}}$ & $41.50^{\mathrm{a}-\mathrm{e}}$ & $4.95^{\mathrm{ab}}$ & $6.95^{\mathrm{c}-\mathrm{f}}$ & $1.45^{\mathrm{a}-\mathrm{d}}$ & $0.46^{\mathrm{c}-\mathrm{e}}$ & $18.47^{\circ}$ & $0.38^{\mathrm{b}}$ & 29.4 \\
\hline 3 & & & $20^{\mathrm{a}-}$ & $41.00^{\mathrm{bc}}$ & $47.50^{\mathrm{a}}$ & $4.97^{\mathrm{ab}}$ & $6.19^{\mathrm{d}-\mathrm{h}}$ & $1.89^{\mathrm{ab}}$ & $0.46^{\mathrm{c}-\mathrm{e}}$ & 18.3 & $0.35^{\mathrm{b}}$ & 8.1 \\
\hline 4 & & -h & $.40^{\mathrm{d}-\mathrm{h}}$ & 19.00 & $23.50^{\mathrm{a}-\mathrm{h}}$ & $2.86^{\mathrm{c}-\mathrm{g}}$ & $3.21^{\mathrm{f}-\mathrm{j}}$ & $0.98^{\mathrm{a}-\mathrm{e}}$ & $0.29^{\mathrm{e}-\mathrm{h}}$ & 11.6 & 0.26 & 4.9 \\
\hline 5 & & $1-\mathrm{k}$ & $9.15^{\mathrm{a}}$ & 30.0 & 24.00 & $3.41^{\mathrm{be}}$ & $9.02^{\mathrm{b}-\mathrm{e}}$ & $1.12^{\mathrm{a}-\mathrm{e}}$ & 04 & & & 0. \\
\hline & & & $.00^{\mathrm{a}-\mathrm{g}}$ & 26.00 & 14 & 2.39 & $5.27^{\mathrm{e}-\mathrm{j}}$ & $0.54^{\mathrm{de}}$ & $34^{\mathrm{e}-\mathrm{h}}$ & & 0.2 & 31.2 \\
\hline 7 & & 1-j & & 36.5 & 19.00 & $3.21^{\mathrm{b}-\mathrm{f}}$ & $6.74^{\mathrm{d}-\mathrm{g}}$ & $1.32^{\mathrm{a}-\mathrm{e}}$ & $47^{\mathrm{c}-}$ & & $0.32^{\mathrm{c}-}$ & 8 \\
\hline & & 301. & 11. & & $12.00^{\mathrm{h}}$ & $1.51^{\mathrm{e}-\mathrm{g}}$ & $3.40^{\mathrm{f}-\mathrm{j}}$ & $0.46^{\mathrm{de}}$ & - & & $0.25^{\mathrm{d}}$ & 3.6 \\
\hline & & 3. & & 23.50 & $6.50^{\mathrm{h}}$ & $1.64^{\mathrm{c}}$ & $6.85^{\mathrm{c}-\mathrm{g}}$ & $0.30^{\mathrm{e}}$ & J. & & $0.34^{b-}$ & 31.2 \\
\hline 0 & & $68.96^{\mathrm{n}}$ & & $9.00^{\mathrm{i}}$ & $16.50^{\mathrm{f}-\mathrm{h}}$ & $1.40^{\mathrm{fg}}$ & $1.78^{\circ}$ & $0.62^{\mathrm{de}}$ & $3^{\text {gh }}$ & $5.22^{\mathrm{gh}}$ & $0.16^{\mathrm{h}}$ & \\
\hline 11 & & 115. & & 15.5 & $42.50^{\mathrm{a}-\mathrm{d}}$ & $3.32^{\mathrm{b-f}}$ & $2.75^{\mathrm{g}-\mathrm{j}}$ & $1.79^{\mathrm{a}-\mathrm{c}}$ & $26^{\mathrm{e}-\mathrm{h}}$ & 10. & $0.25^{\mathrm{d}-}$ & $27.92^{\mathrm{h}}$ \\
\hline 12 & & ef & & 14.5 & $15.00^{\mathrm{f}-\mathrm{h}}$ & $2.04^{\mathrm{d}-\mathrm{g}}$ & $1.87^{\mathrm{ij}}$ & $0.49^{\mathrm{de}}$ & $16^{\mathrm{f}-\mathrm{h}}$ & $6.49^{\mathrm{f}-\mathrm{h}}$ & $0.13^{\mathrm{kl}}$ & 33.11 \\
\hline 13 & & & & 13.5 & $19.00^{\mathrm{c}-\mathrm{h}}$ & $2.01^{\mathrm{d}-\mathrm{g}}$ & $1.84^{\mathrm{j}}$ & $0.47^{\mathrm{de}}$ & $14^{\mathrm{f}-\mathrm{h}}$ & $5.71^{\mathrm{f}-\mathrm{h}}$ & $0.15^{\mathrm{i}-1}$ & $27.76^{\mathrm{h}}$ \\
\hline 14 & & 1 & & 10.50 & $9.50^{\mathrm{h}}$ & $1.25^{\mathrm{g}}$ & $1.53^{\mathrm{j}}$ & $0.30^{\mathrm{e}}$ & $11^{\mathrm{h}}$ & $4.51^{\mathrm{h}}$ & $0.10^{1}$ & $29.54^{\mathrm{e}}$ \\
\hline 15 & & 1 & & 53. & 18 & $3.37^{\mathrm{b}-\mathrm{e}}$ & 10.93 & $0.90^{\mathrm{a}-\mathrm{e}}$ & $0.76^{\mathrm{ab}}$ & 30.4 & $0.44^{\mathrm{a}-\mathrm{C}}$ & $24.53^{\mathrm{k}}$ \\
\hline 16 & & 0 & & 38. & & 3.15 & $16.71^{\mathrm{a}}$ & 1.3 & $0.92^{\mathrm{a}}$ & $36.89^{\mathrm{a}}$ & $0.56^{\mathrm{a}}$ & 24. \\
\hline 17 & & & & 23. & b-h & 2.5 & $5.16^{-J}$ & $0.93^{\mathrm{a}-\mathrm{e}}$ & & $14.12^{\mathrm{e}-\mathrm{t}}$ & $0.29^{-}$ & 32.26 \\
\hline 18 & & 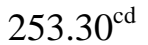 & & 11.0 & & $2.09^{\circ}$ & $1.88^{\mathrm{ij}}$ & $0.66^{\mathrm{c}-\mathrm{e}}$ & $0.18^{\mathrm{f}-\mathrm{h}}$ & $7.23^{\mathrm{f}-\mathrm{h}}$ & $0.14^{\mathrm{j}-1}$ & $34.88^{\mathrm{a}}$ \\
\hline 19 & & 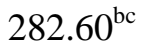 & & 19. & $g^{\text {gh }}$ & $1.88^{\mathrm{c}}$ & $3.08^{\mathrm{f}-\mathrm{j}}$ & $0.57^{\mathrm{de}}$ & $0.21^{\mathrm{e}-\mathrm{h}}$ & 2 & $0.21^{\mathrm{e}-}$ & $27.27^{\mathrm{i}}$ \\
\hline 20 & & 3 & & 22 & b-h & $2.57^{\mathrm{c}-\mathrm{g}}$ & $5.45^{\mathrm{e}-\mathrm{j}}$ & $1.13^{\mathrm{a}-\mathrm{e}}$ & $0.37^{\mathrm{d}-\mathrm{I}}$ & 4.5 & $0.26^{\mathrm{d}-}$ & $26.69^{j}$ \\
\hline 21 & & .2 & & & $a^{a-h}$ & $3.22^{\mathrm{b}}$ & $3.18^{f-j}$ & $1.09^{\mathrm{a}-\mathrm{e}}$ & $0.26^{\mathrm{e}-\mathrm{h}}$ & & $0.30^{\mathrm{c}-}$ & $26.80^{\mathrm{j}}$ \\
\hline 22 & & 2 & & & $0^{\mathrm{ab}}$ & $4.20^{\mathrm{bc}}$ & $2.44^{\mathrm{h}-\mathrm{j}}$ & $1.39^{\mathrm{a}-\mathrm{e}}$ & $0.21^{\mathrm{e}-\mathrm{h}}$ & $8.51^{\mathrm{e}-\mathrm{h}}$ & $0.18^{\mathrm{g}-1}$ & $29.85^{\mathrm{cd}}$ \\
\hline 23 & & 208 & & 13. & $24.00^{\mathrm{a}-\mathrm{h}}$ & $2.19^{\mathrm{d}-\mathrm{g}}$ & $1.99^{\mathrm{ij}}$ & $0.82^{\mathrm{b}-\mathrm{e}}$ & $0.16^{\mathrm{f}-\mathrm{h}}$ & f-h & $0.19^{\mathrm{f}-1}$ & $29.36^{\mathrm{ef}}$ \\
\hline 24 & & & $7.30^{\mathrm{h}}$ & 29. & 43. & $3.73^{\mathrm{b}}$ & $4.82^{\mathrm{f}-\mathrm{j}}$ & $1.96^{\mathrm{a}}$ & $35^{\mathrm{e}-\mathrm{h}}$ & 13. & $0.48^{\mathrm{ab}}$ & 26. \\
\hline 25 & & & $.70^{\mathrm{a}-\mathrm{d}}$ & & & $2.87^{\mathrm{c}}$ & $317^{\mathrm{f}-\mathrm{j}}$ & $0.90^{\mathrm{a}-\mathrm{e}}$ & $0.23^{\mathrm{e}-1}$ & $9.10^{\mathrm{e}-\mathrm{h}}$ & $0.20^{\mathrm{e}-1}$ & $29.75^{\mathrm{d}}$ \\
\hline 26 & & & & & 22 & $3.14^{\mathrm{b}-\mathrm{g}}$ & 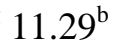 & $1.35^{\mathrm{a}-\mathrm{e}}$ & $077^{3}$ & 0 & $0.53^{\mathrm{a}}$ & $27.13^{\mathrm{i}}$ \\
\hline 27 & & & & 19. & $8.00^{\mathrm{h}}$ & $1.76^{\mathrm{e}-\mathrm{g}}$ & $4.55^{\mathrm{f}-\mathrm{j}}$ & $0.30^{\mathrm{e}}$ & $21^{\mathrm{e}-\mathrm{h}}$ & 12. & $0.31^{\mathrm{c}-}$ & $24.16^{1}$ \\
\hline 28 & & & $7.50^{\mathrm{h}}$ & 150 & $21.00^{\mathrm{b}-}$ & $2.17^{\mathrm{d}-\mathrm{g}}$ & $1100 \mathrm{i}$ & $0.70^{\mathrm{c}-\mathrm{e}}$ & $0.16^{\mathrm{f}-\mathrm{h}}$ & & $0.25^{\mathrm{d}-}$ & $28.23^{\mathrm{g}}$ \\
\hline 29 & & & $0^{\mathrm{a}-}$ & 35.5 & $43.00^{\mathrm{a}-\mathrm{c}}$ & & $6.00^{\mathrm{d}-\mathrm{i}}$ & $1.51^{\mathrm{a}-\mathrm{d}}$ & $0.41^{\mathrm{d}-\mathrm{I}}$ & & $0.35^{\mathrm{b}-}$ & 25.74 \\
\hline 30 & MI & & .24 & 24.50 & $5^{a-\varepsilon}$ & $3.71^{\mathrm{b}}$ & $2.86^{\mathrm{f}-\mathrm{j}}$ & 1.3 & 0 & 9.8 & $0.28^{\mathrm{d}}$ & $29.24^{f}$ \\
\hline & & & & & & & & & & & & \\
\hline & & & & 9.00 & & & & & & & & $3.0^{2}$ \\
\hline & & & 19. & 68. & & 6. & 16.71 & & & & 57 & 34.93 \\
\hline & 2.8 & 12.81 & & 1.2 & 3.56 & 0.5 & 0.2 & $8 .{ }^{2}$ & 12 & 2.92 \\
\hline VIe & & 2.6 & 13.63 & 25.78 & 24.63 & 2.94 & 5.08 & 1.0 & 0.3 & 14.21 & 0.29 & 28.70 \\
\hline
\end{tabular}

Note: Means within a column followed by the same letters are not significantly different at $\mathrm{p}<0.05$ according to LSD test.

Table 4. Phenotypic coefficient of variation, Genotypic coefficient of variation, and genetic standard deviation of some agronomical characters of thirty sweet potato accessions

\begin{tabular}{|c|c|c|c|}
\hline Characters & PCV & GCV $\mathrm{SD}_{\mathrm{g}}$ & Criteria \\
\hline Vines length & 35.75 & 35.201083 .3 & 4Narrow \\
\hline Weight of vines & 20.57 & 15.162 .19 & Broad \\
\hline Number of the saleable root & 49.69 & 42.6043 .13 & Narrow \\
\hline Number of the non-saleable root & 48.68 & 35.0240 .55 & Narrow \\
\hline Number of root per plant & 40.79 & 33.820 .38 & Broad \\
\hline Weight of the saleable root & 70.06 & 64.103 .26 & Broad \\
\hline Weight of the non-saleable root & 49.78 & 31.170 .08 & Broad \\
\hline Weight of root per plant & 59.73 & 52.680 .01 & Broad \\
\hline Root yield & 59.25 & 53.0818 .34 & Broad \\
\hline Harvest index & 42.07 & 34.350 .00 & Broad \\
\hline Dry matter content & 10.16 & 10.152 .16 & Broad \\
\hline
\end{tabular}

Note: $\mathrm{PCV}=$ Phenotypic coefficient of variation, $\mathrm{GCV}=$ Genotypic coefficient of variation $\mathrm{SD}_{\mathrm{g}}=$ standard deviation of genotype 
Table 5. Genotypic variance, phenotypic variance, environment variance, and heritability of some agronomical characters of thirty sweet potato accessions

\begin{tabular}{llllll}
\hline Characters & $\sigma_{\mathrm{g}}^{2}$ & $\sigma_{\mathrm{p}}^{2}$ & $\sigma_{\mathrm{e}}^{2}$ & $\mathrm{H}^{2}(\%)$ Criteria \\
\hline Vines length & 4132.44 & 4263.11 & 261.34 & 96.93 & High \\
Weight of vines & 4.27 & 7.86 & 7.18 & 54.28 & High \\
Number of the saleable root & 120.66 & 164.13 & 86.94 & 73.52 & High \\
Number of the non-saleable root & 74.44 & 143.79 & 138.71 & 51.77 & High \\
Number of root per plant & 0.99 & 1.44 & 0.90 & 68.71 & High \\
Weight of the saleable root & 10.62 & 12.68 & 4.13 & 83.71 & High \\
Weight of the non-saleable root & 0.10 & 0.26 & 0.31 & 38.88 Medium \\
Weight of root per plant & 0.04 & 0.05 & 0.02 & 80.39 High \\
Root yield & 56.87 & 70.84 & 27.95 & 80.27 High \\
Harvest index & 0.01 & 0.015 & 0.01 & 81.27 High \\
Dry matter content & 8.50 & 8.50 & 0.01 & 99.95 & High \\
\hline
\end{tabular}

Note: $\sigma_{\mathrm{g}}^{2}=$ genotypic variance $\sigma_{\mathrm{p}}^{2}=$ phenotypic variance, $\sigma_{\mathrm{e}}^{2}=$ environment variance, $\mathrm{H}^{2}=$ broad-sense heritability

In this study, heritability value showed that almost all of the characters observed have high broad-sense heritability except for the weight of the non-saleable root (Table 5). This result means that the phenotypic appearance of the other 10 characters are more influenced by genetic factors rather than by environmental factors. While the medium heritability value on the character shows that the influence of the environment and genotype is at the same level. The similar result were obtain by Dewi et al., (2019) that reported the weight of vines, number of large root, and weight of root that showed high heritability values. Root yield, harvest index, and root dry matter content also show high heritability values on study by Shumbusha et al., (2019)

High heritability coupled with broad GCV indicated that the characters had additive gene effect and more reliable for effective selection. In this study, the weight of the saleable root per plot, the weight of root per plant, and the root yield showed broad GCV and high broad sense heritability. These results are in agreement with study by Wera et al., (2014), Rahajeng and Rahayuningsih (2016), and Narasimhamurthy et al., (2018).

The broad GCV in a population is effective for selection to obtain a superior variety. PCV estimation was higher than GCV estimation for all the observed characters. Inheritance information is important to determine the criteria for efficient selection in addition to the coefficient of variance. Almost all of the characters observed have high broad-sense heritability except for the weight of the non-saleable root.

Results of this study showed that based on broad GCV dan high heritability, the weight of the saleable root per plot, the weight of root per plant, and the root yield are more reliable for effective selection. The benefit of this study are the 30 accessions can be utilized in sweet potato breeding programs especially for characters which have a broad GCV (the weight of the saleable root per plot, the weight of root per plant, and the root yield) since they can be combined as crossing parents and used these characters as the selection criteria.

\section{CONCLUSIONS}

The results of ANOVA showed the significant difference among the tested genotypes in almost all traits observed except on weight of non-saleable root. PCV estimation was higher than GCV estimation for all the observed characters. The weight of the saleable root per plot, the weight of root per plant, and the root yield showed a wide range of PCV and GCV as well as high broad-sense heritability that indicated these traits to have additive gene effect and more reliable for effective selection. The broad GCV in a population is effective for selection to obtain superior variety. A total of 30 accessions can be utilized in assembling varieties especially for characters which have a broad GCV value.

\section{ACKNOWLEDGEMENTS}

The authors would like to thank the Indonesian Legumes and Tuber Crops Research Institute (ILETRI), the Indonesian Agency for Agricultural Research and Development (IAARD) Ministry of Agriculture for the financial support on DIPA 2017, and to the head and technician of Kendalpayak experimental station for helping during the research.

\section{REFERENCES}

Addisu F., Yohannes P., \& Habtamu Z. (2013). Genetic variability and association between 
agronomic characters in some potato (Solanum tuberosum L.) genotypes in SNNPRS, Ethiopia. International Journal of Biodiversity and Conservation, 5(8), 523-528.

Afuape S.O., Nwankwo I.I.M., Omodamiro R.A., Njoku J.C., Ogbonna C.L., \& Uzuegbu D.C. (2015). Targeted Breeding for Sweetpotato-Based Enterprises: Variability, Genotype-byEnvironment Interaction, Heritability and Correlation Studies of Important Sweetpotato Root Processing Quality Traits. Int. J. Plant Breed. Genet., 9 (4), 206-217,

Akinwale M.G., Akinyele B.O., Dixon A.G.O., \& Odiyi A.C. (2010). Genetic variability among forty-three cassava genotypes in three agroecological zones of Nigeria. Journal of Plant Breeding and Crop Science, 5, 104-109.

Baafi E., Ofori K., Blay E.T., Gracen V.E., ManuAduening J., \& Carey E.E. (2016). Exploitation of Genetic Potential of Sweetpotato for End-User Traits Improvement. African Crop Science Journal, 24(4), 377 - 387.

Badu M., Ashok P., Kiran Patro T.S.K.K., \& Sasikala K. (2017). Studies on Genetic Variability, Heritability and Genetic Advance for Growth, Yield and Quality Parameters among Orange Flesh Sweet Potato [Ipomoea batatas (L.) Lam.] Genotypes. Int.J.Curr.Microbiol.App.Sci, 6(9), 1894-1903

Chahal G.S. \& Gosal S.S. (2010). Principles and Procedures of Plant Breeding: Biotechnology and Conventional Approaches. New Delhi, Chennai, Mumbai and Kolkata, Narosa Publishing House.

Demelie M. \& Aragaw A. (2016). Genetic variability of Sweet Potato on yield and yield related traits at werer Agricultural Research Center. Ethiopia. Electronic Journal of Plant Breeding, 362-370.

Dewi R., Utomo S.D., Kamal M., Timotiwu P.B., \& Nurdjanah S. (2019). Genetic and phenotypic diversity, heritability, and correlation between the quantitative characters on 30 sweet potato germplasms in Lampung, Indonesia. Biodiversitas, 20(2), 380-386.

EL-Sharkawy G.A. (2019). Assessment of Variability, Correlation and Response to Selection in Four Cultivars of Sweet Potato "Ipomoea batatas, L." under Alexandria Environmental Condition. Alex. J. Agric. Sci., 64(1), 21-31.

Irwan M., Rosmayati., Hanafiah D.S., Rahmawati N. \& Bakti D. (2019). Analysis of changes in morphological characteristics of leaves and stems in some sweet potato cultivars (Ipomoea batatas L.) from Simalungun and Dairi highlands planting in the lowlands. IOP Conf. Series: Earth and Environmental Science 260 (2019) 012150 IOP Publishing,
Kuswantoro H., Artari R., Rahajeng W., Ginting E., \& Supeno A. (2018). Genetic Variability, Heritability, and Correlation of Some Agronomical Characters of Soybean Varieties. Biosaintifika, 10(1), 9-15.

Kathabwalika D.M., Chilembwe E.H.C., Mwale V.M., Kambewa D., \& Njoloma J.P. (2013). Plant growth and yield stability of orange fleshed sweet potato (Ipomoea batatas) genotypes in three agroecological zones of Malawi. Int. Res. J. Agric. Sci. Soil Sci., 3(11), 383-39.

Madawal S.L., Alloli, Madarkhandi T.B.S., \& Narasannavar A. (2015). Genetic variability study in sweet potato (Ipomoea batatasL.) genotypes. Inte. J. of Tropical Agric., 33(2), 274-282.

Mbah E.U. \& Eke-Okoro O. (2015). Relationship Between some Growth Parameters, Dry Matter Content and Yield of Some Sweet Potato Genotypes Grown under Rainfed Weathered Ultisols in the Humid Tropics. Journal of Agronomy, 14(3), 121-129.

Narasimhamurthy P.N., Patel N.B., Patel A.I. \& Koteswara Rao G. (2018). Genetic variability, heritability and genetic advance for growth, yield and quality parameters among sweet potato [Ipomoea batatas (L.) lam.] genotypes. International Journal of Chemical Studies, 6(4), 2410-2413.

Ngailo S., Shimelis H., Sibiya J., Amelework B., \& Mtunda K. (2016). Genetic diversity assessment of Tanzanian sweetpotato genotypes using simple sequence repeat markers. South African Journal of Botany, 102, 40-45

Palumbo F., Galvao A.C., Nicoletto C., Sambo P., \& Barcaccia G. (2019). Diversity Analysis of Sweet Potato Genetic Resources Using Morphological and Qualitative Traits and Molecular Markers. Genes, 10(840), 19 pages.

Pradhan D.M.P., Mukherjee A., George J., Chakrabarti S.K.,Vimala B., Naskar S.K., Sahoo B.K., \& Samal S. (2015). High starch, beta carotene and anthocyanin rich sweet potato: ascent to future food and nutrition security in coastal and backward areas. Intl J Trop Agric, 33(2), 397-400 (Part I).

Rahajeng W. \& Rahayuningsih S.A. (2016). Potensi Genetik Klon-Klon Ubijalar Berdasarkan Karakter Agronomi. Prosiding Seminar Nasional Hasil Penelitian Tanaman Aneka Kacang dan Umbi Tahun 2015, 588-595.

Rahajeng W. \& Indiati S.W. (2018). Keragaan Karakter Agronomi dan Parameter Genetik Aksesi Ubi Jalar serta Toleransinya terhadap Hama Boleng. Buletin Palawija,16(1),1-8.

Rukundo P., Shimelis H., Laing M., \& Gahakwa D. (2013). Storage root formation, dry matter 
synthesis, accumulation and genetics in sweet potato. AJCS, 13, 2054-2061.

Selaocoe M.E., Adebola P., Pillay M., \& Laurie M. (2019). Genetic diversity of South African sweetpotato germplasm using molecular markers. Journal of Crop Improvement, 33(6), 814-833.

Shaumi U., Chandria W., Waluyo B., \& Karuniawan A. (2012). Potensi genetik ubijalar unggulan hasil pemuliaan tanaman berdasarkan karakter morfoagronomi. Prosiding Seminar Hasil Penelitian Tanaman Aneka Kacang dan Umbi 2011.

Sharavati M.B., Srinivasa V., Anusha R.B., \& Shubha A.S. (2018). Genetic Variability Studies in Sweet Potato (Ipomoea batatas (L.) Lam) Genotypes under Hill Zone of Karnataka, India. Int.J.Curr.Microbiol.App.Sci., 7(9), 850-858

Shumbusha D., Shimelis H., Laing M., \& Rukundo P. (2019). Gene action and heritability of yield components of dual-purpose sweetpotato clones. Euphytica, 215:122.

Syukur M., Sujiprihati S., \& Yunianti R., (2009). Teknik Pemuliaan Tanaman. Departemen Agronomi dan Hortikultura, Fakultas Pertanian, Institut Pertanian Bogor.

Wera B., Yalu A., Ramakrishna A., \& Deros M. (2014). Genotypic Variability Estimates Of Agronomic Traits For Selection In A Sweetpotato (Ipomoea batatas) Polycross Population In Papua New Guinea. J. Plant Breed. Genet., 02(03), 131136. 